\section{The Challenges of Catholic Universities in Africa: The Role of ACUHIAM}

\section{Michel Lejeune}

Michel Lejeune is vice chancellor of Uganda Martyrs University and chairman of the Association of Catholic Universities and Higher Institutions of Africa and Madagascar. Address: Uganda Martyrs University, PO Box 54498, Kampala, Uganda. E-mail: <vcumu@imul.com>.

$\mathrm{O}$ ver the last decade, Catholic institutions of higher learning have been created and have been undergoing change on the African continent. At a time when postindependence problems are the daily concern of governments and state education appears to be loosing ground, it appears that new ways have to be found to train and prepare new leaders for Africa. Values have been undermined, and strategies have to be found to stop the downhill movement that is affecting societies.

\section{The challenges facing Catholic universi- ties today are enormous.}

In an effort to survive, state-run universities are commercializing some parts of their institutions. It is our contention that this trend will not salvage anything, but only delay the decline of higher education standards in our countries.

More and more private universities are being created to meet the demand created over the years by state universities. Some initiatives are positive; others are a hidden way of creating revenue for a few people. The question is how will higher education be put back on the right track and become relevant to the needs of Africa today? One initiative that should be supported is the effort of the Catholic church to enter the field of higher education.

The Association of Catholic Universities and Higher Institutions of Africa and Madagascar (ACUHIAM) is one example of an association created to improve higher education in Africa

At their last general assembly, held at Uganda Martyrs University in April, ACUHIAM passed some basic resolutions toward creating a common policy in higher education. These steps are simple and attempt to give a clear answer to the real problems of the African continent:

- each Catholic university or higher education institute in Africa wants to be a center of academic excellence; - in the choice of its curricula and subjects of study,
ACUHIAM participants will try to answer the real needs of the country in which they are established;

- ACUHIAM will focus its attention on the poor and underprivileged, so as to give equal opportunity to all; and

- in the pursuit of academic excellence, regional links will be created, leading to broader international cooperation between Catholic universities.

These few clear objectives constitute the basis of ACUHIAM's action program for the coming four years. Isolated efforts cannot accomplish very much, but in collaboration with others some success may be achieved. Projects of a common nature will be identified and this will be the basis of sense of shared identity among African universities and higher education institutes. It is the conviction of ACUHIAM that the poor should be an important target in their endeavors and that it is up to each university to discover the best way to implement this directive.

As a newly established association, ACUHIAM will need support from outside Africa if it wishes to achieve its goals. The will is there, some resources are present, but international solidarity is also an important factor. Member universities are committed to being partners in development, and believe that education is development. The association bases its philosophy on principles drawn from Christianity as the basis for action and is not afraid to tell the world who it is and what it stands for.

The challenges facing Catholic universities today are enormous. Two priorities are academic excellence and service to the poor. A concerted effort by all member institutions, whether existing or yet to come, must be made to put these priorities on their agendas.

\section{It is the conviction of ACUHIAM that the poor should be an important target in their endeavors.}

As private institutions, these universities offer their students the possibility to work and study in an environment that will foster scholarship. At the same time, they help students understand that their position must be geared to the less privileged in society. Barriers can be broken down, and it will depend on the will of all actors involved to make this happen, especially the leading Catholic universities.

The future of ACUHIAM will be what its members want it to be. However, determining the place and role of Catholic universities in the future is a challenge worth taking. Uganda Martyrs University has as its motto "Virtute et Sapientia Duc Mundum." This is perhaps a prophetic way of looking at Catholic Universities in Africa today. 